\title{
BRIDGING THE GAP - TowardS A Transatlantic Approach to Reducing IneQuality: A Policy Proposal
}

\section{Sergio Mukherjee and Håvard Sandvik ${ }^{1}$}

\section{INTRODUCTION}

We met Scott and Kerstin on different sides of the Atlantic. I met the former in Philadelphia on my way to a convenience store in the early hours of a busy morning when my work schedule benefited from a short coffee break. Håvard met Kerstin in Mannheim (Germany) at a local fast-food joint in the Hauptbahnhof of what was once a vibrant industrial town.

More than just worrying figures, the growing gap between those with high and low income speaks to the worrying realities of a sizeable and steadily increasing number of individuals who live in the shadows of rich societies. Although Scott and Kerstin are separated by an ocean, their daily struggles are strikingly similar and capture the human dimension of an issue policy makers in both North America and Europe can no longer ignore.

We argue that greater actions to make growth more inclusive ought to be part of a joint effort that addresses global and local inequalities. Development may certainly benefit from economic growth, but seeing growth as the ultimate goal in a developmental project ${ }^{2}$ can easily miss the point that many rapidly

\footnotetext{
1 Sergio Mukherjee is a 2016-2017 Alexander von Humboldt Fellow in Germany working on local processes for refugee integration in the south of the country. His research interests and doctoral training at the University of Pennsylvania include the political economy of development and comparative politics with a focus on education. He was an undergraduate at Cornell University. Håvard Sandvik is a Policy Advisor for the Liberal Group in the Norwegian Parliament, focusing on labor, social affairs, local government and administration. Sandvik graduated with a Magister Artium in Political Science from the Ruprecht Karl University in Heidelberg, Germany and a BA in International Studies from the University of Stellenbosch in South Africa.

2 For a detailed discussion on this point, see Jean Dreze and Amartya Sen (2013) An Uncertain Glory: India and its Contradictions. Or Sen's recent debates on the issue with economist Jagdish Bhagwati, as
} 
growing countries in the last decades have not managed to reduce deep social inequalities and deprivations that confine citizens to vulnerable lives. ${ }^{3}$ Any starting point for discussions on inequality, growth, or development should not conflate the latter two.

Part of the problem is that an exclusive focus on growth, defined as the increase in a country's productive capacity by comparing the monetary value of the goods and services produced by a country (GDP) within two successive periods of time, overlooks the potential inequality of distribution and access to important social services, such as adequate schooling and healthcare. While it is true that the nature and extent of poverty and inequality vary across the world, both relative and extreme poverty restrict people to operate at the margins of society. As a result, people not only have limited access to resources but also become more prone to poor health, indebtedness, educational disadvantages, inadequate housing, and crime as shown by extensive empirical studies. ${ }^{4}$

Despite the overall wealth ${ }^{5}$ of the European Union (EU), socio-economic vulnerability within several member states is still at a relatively high level with nearly 1 in 7 people at risk of poverty. The figures are even higher for certain demographics such as children and the elderly. ${ }^{6}$ In the US, the number of poor people recently reached 46.2 million - a record-high, amounting to $15 \%$ of the population. In addition, 4 out of 5 Americans struggle with joblessness or rely on welfare for at least part of their lives, and to make matters worse, the income gap in the country between the richest 1\% of Americans and the other 99\% widened to a record figure last year ${ }^{7}$ — such numbers give an elusive flavor to the American

well as earlier works such as Growth Economics (1970), published by Penguin.

3 Examples include developing and developed countries, such as India, South Africa, Israel, Romania, Bulgaria, US, UK etc.

4 The very consequences of growing income inequality may not be as straight-forward as one would think. Surveying part of a vast literature, we find ample empirical evidence to support the negative impact that income inequality has on life satisfaction (Hirschman and Rothschild 1973, Senik 2006, Alesina et al 2004, Schwarze and Harpfer 2007) as well as a significant effect on homicide and robbery (Fajnzylber et al. 2002), trust and civic cooperation Knack and Keefer (1997), probability of not enrolling in college (Acemoglu and Pischke 2001), indebtedness (Rajan 2010).

5 If seen as a single country, the EU would constitute the second largest economy in the world in nominal terms and PPP (purchasing power parity) with a GDP of approximately 16 trillion Euros in 2016.

6 EAPN: Poverty and Inequality in the European Union <http://www.poverty.org.uk/summary/eapn. $\underline{\text { shtml> }}$

7 See Emmanuel Saez \& Gabriel Zucman (2016), "Wealth Inequality in the United States since 1913:

Evidence from Capitalized Income Tax Data," The Quarterly Journal of Economics, vol 131(2), pages 519- 
dream.

Among wealthier states, inequality first started to significantly increase in the late 1970s and early 1980s, notably in the United Kingdom and the United States. The 2000s witnessed a widening gap between rich and poor, not only in high-inequality countries such as the United States, but also in historically low-inequality countries, such as Germany, Denmark, and Sweden. ${ }^{8}$ Globally, by 2011 , the richest 20 percent of the world's population controlled 80 percent of global income. ${ }^{9}$ Even if not every country is growing increasingly unequal, the point is that enough of them are, including developing regions, the US and parts of Europe. The sheer scale of deprivation and vulnerability that afflicts so many people is enough to warrant a serious and well-coordinated agenda to combat this issue. Rhetorically, the impetus seems to be there as articulated by President Obama last year: "The United States will join with our allies to eradicate such extreme poverty in the next two decades. ${ }^{10}$ " At present, however, there are still plenty of gaps, including those between collective coordination between official intention and concrete action.

\section{The Risks of Omission and the Trade-offs of Trade}

By failing to ensure that economic growth is an inclusive process that embraces both the advantaged and the disadvantaged in society, the threat to stability, social cohesion, and progress will continue to loom large both for transatlantic partners and the world at large. Evidence pointing to higher incidence of violent crimes in more unequal societies and the higher rate of emotional and physical violence experienced by children living in more unequal places are just two examples of several dimensions that limit social stability.

\footnotetext{
578. For a less technical overview, see "US income inequality at record high" BBC News (September 10, 2013) http://www.bbc.co.uk/news/world-us-canada-24039202 as well as Emanuel Saez (2013) Striking it Richer: The Evolution of Top Incomes in the United States(Updated with 2012 preliminary estimates). UC Berkeley

8 OECD (2008): Growing unequal? Income distribution and poverty in OECD countries, OECD,Paris

9 Mark Furness and Mario Negre (2012) Deutsches Institut für Entwicklungspolitik, Briefing Paper $14 / 2012$ "Can the EU confront inequality in developing countries?» p. 1

10 President Obama, 2013 State of the Union Address.
} 
Figure 1:

\section{Children Experience More Conflict in More Unequal Societies}

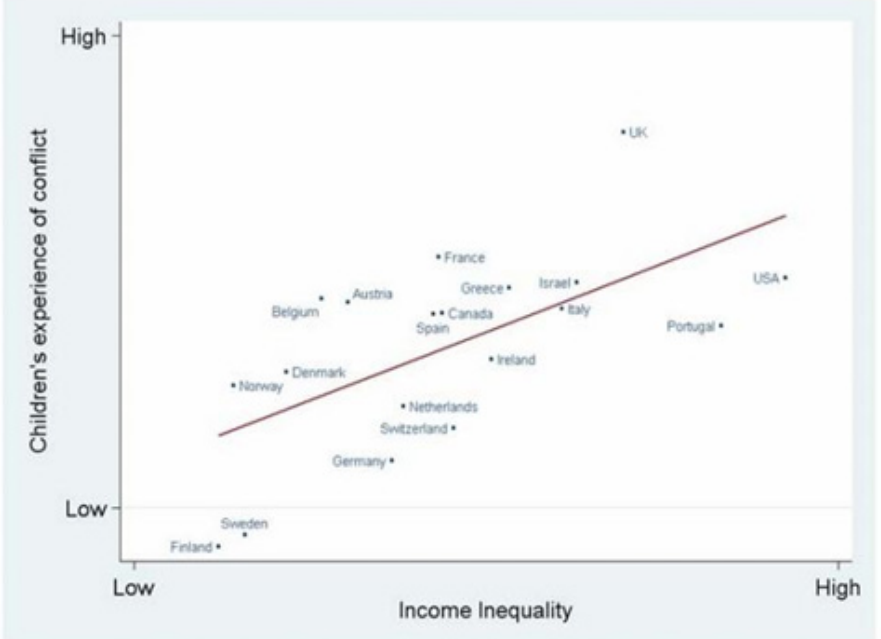

$11,13 \& 15$ yr olds fighting, bullying, and finding peers not kind \& helpful

Figure 2:

Homicide Rates are Higher in More Unequal Rich Countries

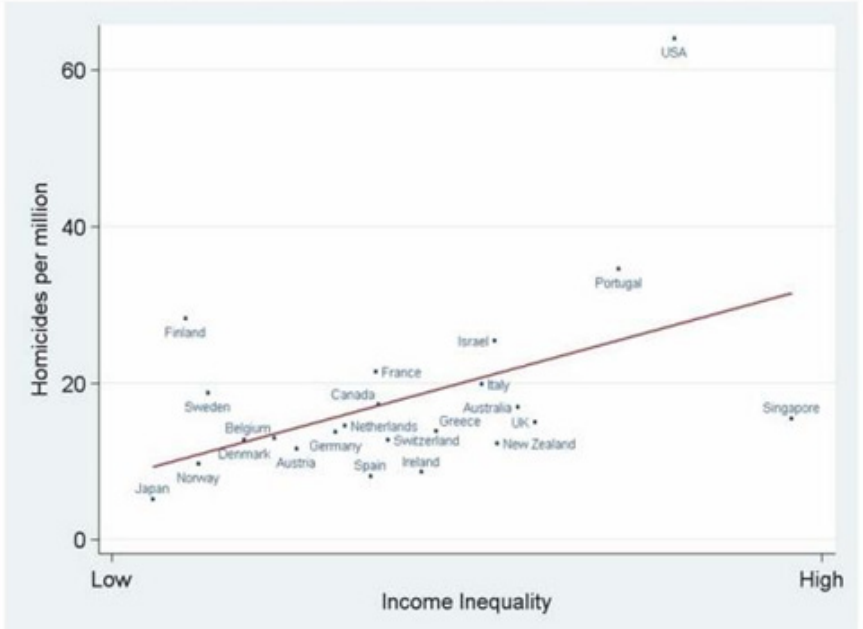


Among countries that until recently were set to play a pivotal role in the global economy, we notice vast and persistent inequalities (see figure 3). Skewed income distribution coupled with shaky social foundations (See figures 1-2) stand in the way of sustained economic progress and the immediate stability of the social terrain in which millions attempt to live meaningful lives.

Figure 3:

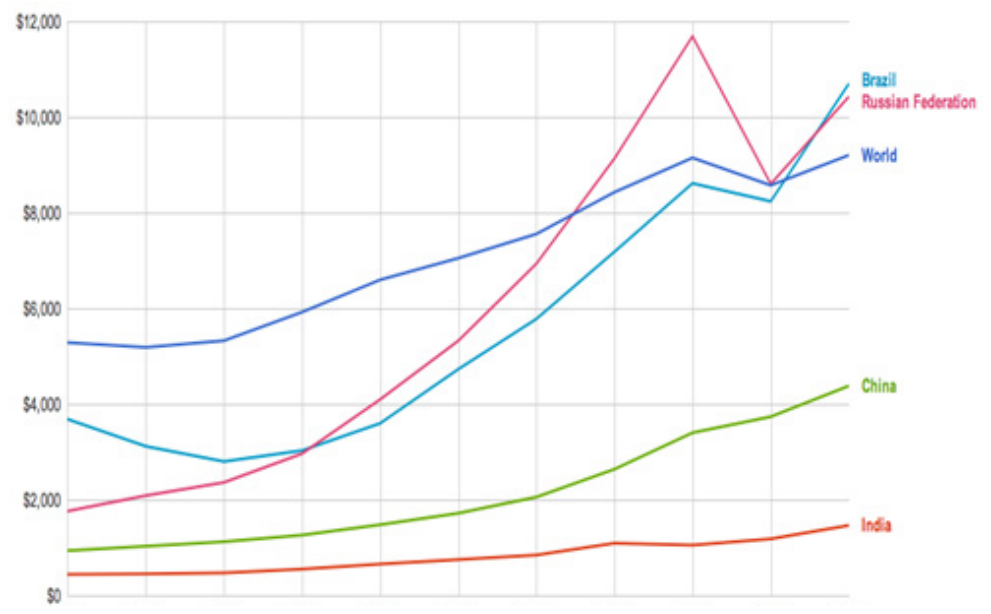

\section{INEQUALITY AND THE 21ST CENTURY}

The final decade of the $20^{\text {th }}$ century and the first of the $21^{\text {st }}$ were shaped by an initial enthusiasm for multilateral removal of trade barriers followed by the eventual disillusionment with the Doha round of negotiations in the WTO. In parallel, the past decade has offered a strategic re-think of development aid in Europe, as the emergence of the BRICS (Brazil, Russia, India, China, and South Africa) and the stagnation of less trade-oriented countries seemed to uphold the Washington consensus. ${ }^{11}$ The challenge seemed no longer how to equitably distribute the benefits of resources, but to further remove the obstacles that ensure the kind of unbridled growth so celebrated, at least initially, in places like India and China. The debate in South Africa confirmed this attitude when much praise was directed at Finance Minister Trevor Manuel for ensuring macroeco-

\footnotetext{
11 Jim O'Neill (2011), The Growth Map: Economic opportunity in the BRICs and beyond, New York: Portfolio/Penguin.
} 
nomic stability at the expense of increasing inequality.

In this context, the two leading mantras, aid and trade, were posited in diametrically opposite corners with no space for confluence. In the process, Europe's own past successes, including the development of one of the most inclusive growth projects the world has ever seen, were forgotten in favor of a developmental policy that increasingly rested on the notion that trade, if left unfettered, would solve all challenges and level the playing field. Not surprisingly, in the EU's "Agenda for Change", inequality is only mentioned once, and even then, in the context of trade. ${ }^{12}$ Even the EU aid commissioner had been forced to take a backseat to the Trade Commissioner in view of the latter's renewed commitment to the benefits of growth through trade.

Globally too, the fields are far from leveled, including in places like India that embraced economic liberalization in the early 90s and prided itself for being until recent times the fastest growing democracy in the world. As Nobel laureate, Amartya Sen, and Jean Drèze remind us, while India today might be staggeringly wealthier in a GDP per capita outlook than twenty years ago, it still lags behind in many social indicators in when compared to its South Asian neighbors. ${ }^{13}$ The same can be said of the development in South Africa. China, on the other hand, has focused to some extent on inequality-redressing-focused policies, as has Brazil over the past ten years. The results have been a steadily expanding middle class in both countries, reduced inequalities, and lessons for the rest of the world, including the transatlantic partners to which we now turn. ${ }^{14}$

\section{LESSONS FROM THE SOUTH}

Conditional cash transfers (CCTs) are commonly associated with Latin America. In the Brazilian case, they started at the municipal level while the first large-scale program (known as Oportunidades ${ }^{15}$ ) took place in Mexico. At their core, CCTs' goals include the reduction of poverty and inequality by combining monetary benefits with incentives for inoculation and education while restricting child labor. Since its establishment 10 years ago, Brazil's Bolsa Familia (family grant) program

\footnotetext{
12 Mark Furness and Mario Negre (2012) Deutsches Institut für Entwicklungspolitik, Briefing Paper $14 / 2012$ «Can the EU confront inequality in developing countries?» p. 2

13 See Jean Dreze and Amartya Sen (Nov. 14 $\left.{ }^{\text {th }}, 2011\right)$ «Putting Growth in Its Place» Outlook Magazine.

14 Benedicte Bull (2013) «Bistand, likhet og nyliberal dårskap» in Morgenbladet (24 October 2013)

15 Its predecessor, Progressa, was created in 1997.
} 
is credited for reducing by $15 \%$ the country's notoriously high income inequality and for lowering the percentage of those living in extreme poverty from $8 \%$ in 2001 to $4.7 \%$ in 2011 . $^{16}$

While cash provides instant economic relief, the built-in conditionalities advance medium to long term social investments in human capital aimed at helping families transcend cycles of poverty in through intergenerational social mobility. Latin America's innovation, ${ }^{17}$ moving from unconditional cash transfers to conditional ones serves as an example to developed and developing countries alike. What started locally has since spread to different parts of the world, including New York City. CCTs' appeal is based on a track record of success that includes their relative low cost and the general reliability of transfer. Brazil's Bolsa Familia, the largest CCT to date of its kind, costs less than 0.5\% of GDP. Critics and criticisms exist including an alleged rural bias since urban setting present a host of additional challenges (including higher rates of crime) that goes beyond the existential needs that the program manages to address in the countryside. Far from being a magic bullet, CCTs are in our view a welcome, and improvable, step in the direction of social protection and inclusion. They are also proof that policy innovations can be exported and implemented in different contexts where individuals suffer from similar structural challenges. We thus believe that transatlantic partners can draw inspiration from the model to foster a new kind of social contract within their own societies to better address inequality during a period in which more traditional forms of aid are contested.

\section{Does Aid Need Help?}

Within Europe, development aid has suffered a major blow as a result of the global economic crisis. In some countries, such as Greece, aid was reduced by $17 \%$ from 2011 to $2012 .{ }^{18}$ For major donors such as France, national aid budgets have atso-been slashed. EU member states might remain the largest donor group in the world, but their input is diminishing and being re-directed towards the promotion of growth in GDP per capita rather than in reducing inequality.

\footnotetext{
16 Add reference of new book on Bolsa Familia

17 While Brazil has done much to address the evil of inequality, it is worth noting that socio-economic challenges still remain that were subject of recent manifestations across the country.

18 OECD (2011) "Aid to poor countries slips further as governments tighten budgets" http://www.oecd. org/dac/stats/aidtopoorcountriesslipsfurtherasgovernmentstightenbudgets.htm
} 
Solidarity, once a hallmark of European progressiveness, has been put to a test as bailouts and generous loans have made headlines in most net-giver countries. In addition, one witnesses a growing dismissal of traditional development aid across the region. In Germany, Angela Merkel's has in her second term already restructured development funds and directed them towards growth, benefiting German companies in the process. ${ }^{19}$ Meanwhile, inequality in the country has been on the rise in the last 10 years $^{20}$.

\section{Figure 4:}

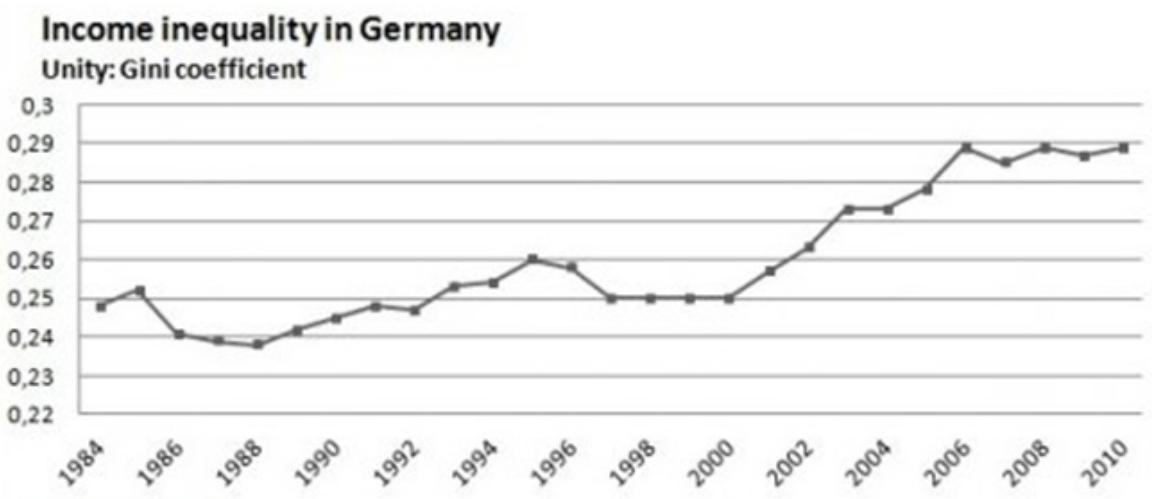

Source: SOEP/OIW

In neighboring Netherlands, the Ministry of Trade recently merged with that the Ministry of Development on the basis that they "should seize the opportunity to let aid encourage much larger private investment and trade activities that benefit both people and the environment, create jobs and transfer knowledge and skills." The change in Dutch discourse reflects a more general disillusionment with traditional development aid. Nevertheless, over-emphasizing the role of the market, as Minister Ploumen risks, might translate into growth at the cost of higher inequality. The European model of the past, including the liberal Dutch approach of Minister

\footnotetext{
19 Peter Carstens (2013), Herkules und die Hirse-Schüsseln“ on FAZ.net http://www.faz.net/aktuell/ politik/inland/entwicklungspolitik-herkules-und-die-hirse-schuesseln-12223838.html

20 Germany's Gini coefficient has gone from 0.25 in the year 2000 to 0.29 by 2010 . For further details see: IW - Inequality Watch (2013) The Evolution of Income Inequalities in Germany.
} 
Ploumen's own party, had been key to ensuring intergenerational social mobility. This is the model we believe the Netherlands and the EU more generally could do well to underscore at home and collaboratively export to countries abroad.

\section{THE RoAD ForWARD}

As Europe and North America continue to shape a multipolar economic world, the need for stability and inclusion is ever present. Their lack of a concerted effort combined with a conceptual inertia that thus far has failed to prioritize distribution at the expense of growth has marginalized the issue of inequality away from the transatlantic radar screen. If transatlanticism is to live up to its promise of shaping the $21^{\text {st }}$ century as much as it has the $20^{\text {th }}$, governments and multilateral organizations must take an approach to both local and global inequality that is mindful of the risks of neglecting this issue.

In addition, by pursuing a coordinated developmental agenda that expands their ttention from continuous growth to both poverty and inequality reduction, North America and Europe can benefit from the individual strengths of each continent's approach to official development aid (ODA) as well as from successful programs world-wide, as the Brazilian case described above. More specifically, USAID's strong global record of working with grassroots organizations and establishing long-term ties with local actors could help European initiatives to address inequality and poverty-reduction from the bottom-up. At the same time, the efficient coordination of development policy, which we see at the EU level, could be a model for a stronger transatlantic cooperation. Before this step, however, a transatlantic declaration, similar to the Paris declaration by EU members on development aid could help define a common set of development priorities that go beyond President Obama's well intentioned vision. Ultimately, it is by working together that both sides of the Atlantic will bridge local, as well as global, socio-economic gaps.

As we await newer policies, Scott and Kerstin remind us that delays have real impacts. "At least I got these jobs, you know?" Scott says with a sigh of relief. "It could be worse."

But it should be much better. 


\section{Bibliography}

Acemoglu, D., \& Pischke, J.-S. (2001, May). Changes in the Wage Structure, Family Income, and Children's Education. European Economic Review, 45(4-6), 890-904.

Alesina, A., Di Tella, R., \& MacCulloch, R. (2004). Inequality and Happiness: Are Europeans and Americans Different? Journal of Public Economics, 88(910), 2009-2042.

Braveman, P. (2002a). Measuring Health Equity Within Countries: The Challenge of Limited Information. Journal of the American Medical Association 288 (October 2, 2002).

Bourguignon, F., Ferreira, H.G.., and Leite, P.G. (2002). "Ex-Ante Evaluation of Conditional Cash Transfers Programs: 'The Case of Bolsa Escola', paper at conference on the The Economics of Child Labour, Oslo. www.ucw-projects.org/events

Bull, Benedicte (24 October 2013) «Bistand, likhet og nyliberal dårskap» in Morgenbladet

Carstens, Peter (2013) in „Herkules und die Hirse-Schüsseln“ on FAZ.net (http://www.faz.net/aktuell/politik/inland/entwicklungspolitik-herkules-und-die-hirse-schuesseln-12223838.html)

Christoffersen, John "Robert Shiller: Income Inequality Is 'Most Important Problem" in Huffington Post (15 October 2013) <http://www.huffingtonpost. com/2013/10/15/shiller-income-inequality-problem_n_4100509.html>

Drèze, Jean and Amartya Sen (2013). An Uncertain Glory: India and its Contradictions. Princeton University Press.

Dreze, Jean and Amartya Sen (1989). Hunger and Public Action. Oxford, Clarendon Press.

EAPN: Poverty and Inequality in the European Union < http://www.poverty.org. uk/summary/eapn.shtml> 
Fajnzylber, P., Lederman, D., \& Norman, L. (2002a). What causes violent crime? European Economic Review, 46(7), 1323-1357.

Fischer, Stanely (1997). Applied Economics in Action: IMF Programs. The American Economic Review, Vol. 87, No. 2 (May 1997).

Furness, Mark and Negre, Mario (2012) "Can the EU confront inequality in developing countries?” Briefing Paper 14/2012 Deutsches Institut für Entwicklungspolitik

Hirschman, A. O., and Rothschild, M. (1973). The Changing Tolerance for Income Inequality in the Course of Economic Development. Quarterly Journal of Economics, 87(4), 544-566.

IPEA (2013). Instituto de Pesquisa Econômica Aplicada http://www.ipea.gov.br/ portal/index.php?option=com_content\&view=article\&id=20391

Inequality Watch (2013). The Evolution of Income Inequalities in Germany. IW

Knack, S., \& Keefer, P. (1997). Does Social Capital Have an Economic Payoff? A Cross-Country Investigation. The Quarterly Journal of Economics, 112(4), 1251-1588.

OECD (2008). Growing unequal? Income distribution and poverty in OECD countries, OECD,Paris.

OECD (2011) "Aid to poor countries slips further as governments tighten budgets" http://www.oecd.org/dac/stats/aidtopoorcountriesslipsfurtherasgovernmentstightenbudgets.htm

O'Neill, Jim (2011), The Growth Map: Economic opportunity in the BRICs and beyond, New York: Portfolio/Penguin

Rajan, R G (2010). Fault lines: How hidden fractures still threaten the world econ- 
omy, Princeton University Press, Princeton.

Saez, Emanuel (2013). Striking it Richer:The Evolution of Top Incomes in the United States(Updated with 2012 preliminary estimates). UC Berkeley

Senik, C. (2006). Ambition and Jealousy: Income Interactions in the "Old" Europe Versus the "New" Europe and the United States. IZA Discussion Paper No. 2083.

Schwarze, J., \& Harpfer, M. (2007). Are People Inequality Averse, and Do They Prefer Redistribution by the State? Evidence from German Longitudinal Data On Life Statisfaction. Journal of Socio-Economics, 36(2), 233-249.

Vasconcelos, Álvaro de (2011). ESPAS Report on Global Trends 2030. Citizens in an Interconnected and Polycentric World. European Union Institute for Security Studies. 